\title{
KOMPARASI HASIL BELAJAR MATEMATIKA MELALUI PENDEKATAN PROBLEM SOLVING DAN PROBLEM POSING PADA SISWA KELAS IV SD SWASTA RAMA SEJAHTERA KOTA MAKASSAR
}

\author{
Erwin Nurdiansyah ${ }^{1}$, Dinar Riaddin ${ }^{2}$ \\ Universitas Islam Makassar ${ }^{1}$, Universitas Agama Islam Negeri Ambon ${ }^{2}$ \\ pos-el : erwinnurdiansyah.dty@uim-makassar.ac.id ${ }^{1}$, dinar.riaddin@iainambon.ac.id ${ }^{2}$
}

\begin{abstract}
ABSTRAK
Jenis penelitian ini adalah penelitian eksperimen yang melibatkan dua kelompok yang diberi perlakuan yang berbeda. Penelitian ini bertujuan untuk mengetahui (1) Seberapa besar hasil belajar matematika siswa kelas IV SD Swasta Rama Sejahtera Kota Makassar yang diajar dengan menggunakan pendekatan problem solving, (2) Seberapa besar hasil belajar matematika siswa kelas IV SD Swasta Rama Sejahtera Kota Makassar yang diajar dengan menggunakan pendekatan problem posing , (3) Ada tidaknya perbedaan hasil belajar matematika siswa kelas IV SD Swasta Rama Sejahtera Kota Makassar antara yang diajar dengan menggunakan pendekatan problem solving dan yang diajar dengan menggunakan pendekatan problem posing. Populasi penelitian ini adalah siswa kelas IV SD Swasta Rama Sejahtera Kota Makassar pada semester genap 2018/2019 yang terdiri dari 3 kelas dan dipilih secara acak 2 kelas sebagai sampel penelitian. Teknik pengumpulan data dilakukan dengan menggunakan tes hasil belajar (Pretest dan posttest) dan lembar observasi.Data yang terkumpul dianalisis dengan menggunakan teknik analisis statistika deskriptif dan inferensial, yaitu uji independent sample $t$ test. Hasil yang diperoleh dari analisis statistika deskriptif adalah: (1) Hasil belajar matematika siswa yang diajar dengan menggunakan pendekatan problem solving berada dalam kategori tinggi dengan rata-rata 73,36 dan standar deviasi 10,20 dari skor ideal 100. (2) Hasil belajar matematika siswa yang diajar dengan pendekatan problem posing berada dalam kategori rendah dengan rata-rata 67,96 dan standar deviasi 8,29 dari skor ideal 100. Dari hasil analisis statistika inferensial diperoleh kesimpulan bahwa hasil belajar matematika siswa yang diajar dengan pendekatan problem solving berbeda dengan hasil belajar matematika siswa yang diajar dengan menggunakan pendekatan problem posing.
\end{abstract}

Kata kunci : hasil belajar matematika, problem solving dan problem posing

\section{ABSTRACT}

This type of research is an experimental study involving two groups given different treatments. This study aims to find out (1) how much the mathematics learning outcomes of fourth grade students of Makassar City Rama Sejahtera Private Elementary School were taught using a problem solving approach, (2) How much the mathematics learning outcomes of fourth grade Rama Sejahtera Private Elementary School Makassar were taught using the problem posing approach, (3) There is a difference between the results of mathematics learning in fourth grade students of Rama Sejahtera Private Elementary School in Makassar City between those taught using a problem solving approach and those taught using a problem posing approach. The population of this study was fourth grade students of Makassar City Rama Sejahtera Private Elementary School in the even semester 2018/2019 which consisted of 3 classes and 2 randomly selected classes as the research sample. Data collection techniques were carried out using learning outcomes tests (pretest and posttest) and observation sheets. The collected data was analyzed using descriptive and inferential statistical analysis techniques, that isindependent sample t-test. The results obtained from descriptive statistical analysis are: (1) Mathematics learning outcomes of students taught by using problem solving approaches are in the high 
category with an average of 73.36 and standard deviation of 10.20 of the ideal score of 100. (2) Learning outcomes Mathematics students taught by the problem posing approach are in the low category with an average of 67.96 and standard deviation of 8.29 from the ideal score of 100. From the results of inferential statistical analysis it can be concluded that the mathematics learning outcomes of students taught by problem solving approaches are different from mathematics learning outcomes of students taught by using the problem posing approach.

Keywords : mathematics learning outcomes, problem solving and problem posing

\section{PENDAHULUAN}

Salah satu mata pelajaran yang dianggap penting dalam mencapai tujuan pendidikan dan ilmu pengetahuan adalah pelajaran matematika yang merupakan sarana berpikir logis, analisis dan sistematis. Melalui pelajaran matematika, seseorang akan mampu mengetahui mata rantai penalaran dan kaidah-kaidah yang dimiliki dalam pelajaran lainnya. Selain itu juga mampu membangun model atau instrumen dari gejala keilmuwan yang telah diamatinya.Hal ini berarti bahwa melalui pelajaran matematika, seorang siswa diharapkan memiliki kemampuan dan keterampilan dalam melakukan penalaran, berpikir kritis, dan logis dalam mengembangkan IPTEK (ilmu pengetahuan dan teknologi) dan IMTAQ (Iman dan taqwa).

Membekali peserta didik dengan matematika, memerlukan perhatian yang sangat khusus kepada murid SD sebagai jenjang pendidikan dasar, karena mereka memiliki cara berfikir yang masih pada tahap operasi yang mudah atau nyata, sementara obyek yang akan ditelaah dalam ruang lingkup matematika bersifat abstrak yang memerlukan pemikiran yang lebih tinggi.

Berdasarkan observasi yang telah dilakukan pada tanggal 12 November 2018 melalui wawancara dengan guru kelas IV SD Swasta Rama Sejahtera Kota Makassar, diperoleh keterangan bahwa hasil belajar matematika murid kelas IV di sekolah tersebut masih tergolong rendah. Hal ini dapat dilihat pada buku daftar nilai MID semester ganjil tahun ajaran 2018/2019 pada kelas tersebut, nilai rata-rata semester ganjil murid hanya 62,75 . Nilai rata-rata ini jika dibandingkan dengan kriteria ketuntasan minimum (KKM) yakni sebesar 65, maka dapat dikatakan bahwa nilai tersebut berada dibawah standar ketuntasan yang diharapkan.Hal ini disebabkan karena murid hanya bekerja sendiri dimana kemampuan mereka dalam menyelesaikan soal sangat minim dikarenakan mereka kurang memahami maksud dari soalsoal yang diberikan. Selama ini mereka hanya menerima apa saja yang diberikan oleh guru dan tidak pernah bertanya kepada guru atau teman yang lebih tahu jika mereka mengalamai kesulitan dan murid yang bisa menjawab tidak mau memberikan penjelasan kepada murid lain yang belum mengerti. Selain itu, situasi anak yang kurang siap menerima materi karena dihadapkan pada keabstrakan matematika, kemudian proses belajar mengajar di kelas yang cenderung berpusat ke guru, maka akan sangat memungkinkan ketidakpahaman murid dalam belajar matematika. Hal ini akanberdampak pada murid yang cenderung manghafal tanpa ada motivasi yang jelas dan mereka cenderung menganggap bahwa matematika adalah suatu masalah yang besar ketika dia dihadapkan pada materi 
yang sangat sulit. Masalah yang timbul ini akan memberikan konstribusi yang jelek pada kualitas dan hasil belajar murid

Menghadapi persoalan pendidikan tersebut diatas, yang sangat berperan adalah guru. Dapat dikatakan bahwa dipundak seorang gurulah terletak mutu pendidikan. Salah satu upaya yang dapat dilakukan oleh guru terutama guru matematika dalam rangka peningkatan mutu pendidikan matematika adalah penerapan berbagai model pengajaran, metode pengajaran hingga pemilihan media pendidikan yang baik, agar materi yang disampaikan dapat diserap dengan baik oleh murid, serta tidak membuat murid jenuh dan dapat meningkatkan motivasi murid dalam belajar.

Oleh karena itu, kegiatan belajar mengajar matematika seyogyanya tidak disamakan begitu saja dengan ilmu lain, karena peserta didik yang belajar matematika itupun berbeda-beda pula kemampuannya, maka kegiatan belajar mengajar haruslah diatur sekaligus memperhatikan kemampuan yang belajar dan hakekat matematika itu serta diperlukan adanya pendekatan yang dipandang sejalan dengan kondisi siswa. Pendekatan yang dianggap sangat relevan adalah problem solving dan problem posing. Problem solving sangat cocok dalam pelajaran matematika, mengingat masih banyak siswa yang merasa kesulitan dalam mengkonstruksikan dan mengaplikasikan ide-idenya dalam memecahkan masalah. Sedangkan problem posing adalah salah satu pendekatan yang mengantarkan peserta didik pada suatu masalah dan menelaah masalah dari bermacam-macam segi, serta merumuskan masalah kemudian mencari pemecahan masalah dengan berbagai macam cara yang coba diterapkan.

Pendekatan pembelajaran problem posing dan problem solving adalah dua di antara banyak pendekatan pembelajaran yang biasa digunakan dalam pembelajaran matematika karena melibatkan aktivitas peserta didik dan juga kreativitas mereka dalam proses pembelajarannya. Siswono (2008) menyatakan problem posing merupakan tugas yang meminta siswa untuk mengajukan atau membuat soal atau masalah berdasar informasi yang diberikan, sekaligus menyelesaikan soal atau masalah yang dibuat tersebut. Pendekatan pembelajaran problem solving mempunyai pengertian sebagai proses pembelajaran yang menuntut peserta didik untuk menyelesaikan masalah, yang dapat dibuat sendiri oleh pendidik ataupun fakta nyata yang ada di lingkungan kemudian diselesaikan dalam pembelajaran di kelas, dengan berbagai cara dan teknik.

Kelebihan pendekatan problem solving, yaitu: 1) Mendidik siswa untuk berpikir secara sistematis, 2) Mampu mencari berbagai jalan keluar darri kesulitan yang di hadapi, 3) Belajar menganalisis siswa suatu masalah dari berbagai aspek, 4) Mendidik siswa percaya diri sendiri. Sedangkan, Kelebihan pendekatan problem posing, yaitu: 1) Kegiatan pembelajaran tidak perpusat pada guru, tetapi dituntut keaktifan siswa, 2) Minat siswa dalam pembelajaran matematika lebih besar dan siswa lebuh mudah memahami soal karena dibuat sendiri, 3) Siswa terpacu untuk keterlibatan secara aktif dalam membuat soal, 4) Dengan membuat soal dapat menilbulkan dampak terhadap kemampuan siswa dalam menyelesaikan masalah, 5) Dapat membantu siswa melihat permasalahan yang ada dan baru diterima sehingga diharapkan mendapat pemahaman yang 
mendalah, 6) Merangsang siswa untuk memunculkan ide kreatif dari yang diperoleh dan memerlukan bahasan atau pengetahuan, 7) Siswa dapat memahami soal sebagai latihan untuk memecahkan masalah.

Berdasarkan uraian di atas, maka penulis tertarik untuk melakukan penelitian tentang "Komparasi Hasil Belajar Matematika Melalui Pendekatan Problem Solving dan Problem Posing pada Siswa Kelas IV SD Swasta Rama Sejahtera Kota Makassar".

Berdasarkan latar belakang diatas, maka masalah-masalah yang akan diteliti dalam penelitian ini adalah sebagai berikut:

1. Seberapa besar hasil belajar matematika siswa kelas IV SD Swasta Rama Sejahtera Kota Makassar yang diajar dengan menggunakan pendekatan problem solving?

2. Seberapa besar hasil belajar matematika siswa kelas IV SD Swasta Rama Sejahtera Kota Makassar yang diajar dengan menggunakan pendekatan problem posing ?

3. Apakah ada perbedaan hasil belajar matematika siswa kelas IV SD Swasta Rama Sejahtera Kota Makassar antara yang diajar dengan menggunakan pendekatan problem solving dan yang diajar dengan menggunakan pendekatan problem posing ?

Tujuan dari penelitian ini adalah sebagai berikut:

1. Untuk mengetahui hasil belajar matematika siswa IV SD Swasta Rama Sejahtera Kota Makassar yang diajar dengan menggunakan pendekatan problem solving.

2. Untuk mengetahui hasil belajar matematika siswa kelas kelas IV SD Swasta Rama Sejahtera Kota Makassar yang diajar dengan menggunakan pendekatan problem posing.

3. Untuk mengetahui perbedaan hasil belajar matematika siswa kelas IV SD Swasta Rama Sejahtera Kota Makassar antara yang diajar dengan menggunakan pendekatan problem solving dan yang diajar menggunakan pendekatan problem posing.

Manfaat yang diharapkan dari penelitian ini adalah:

1. Bagi siswa, dengan penelitian ini diharapkan dapat meningkatkan hasil belajar siswa.

2. Bagi guru, meningkatkan profesionalime seorang guru dan memberikan informasi tentang kemajuan yang diperoleh siswa.

3. Bagi sekolah, sebagai informasi yang dapat dijadikan bahan pertimbangan atau masukan untuk mendapatkan pola pembelajaran yang baik dalam setiap proses pembelajaran.

4. Bagi peneliti, diharapkan dapat memperoleh pengalaman langsung dalam menerapkan pendekatan problem solving dan problem posing, sekaligus memberi motivasi bagi peneliti lain untuk melakukan penelitian sejenis.

\section{METODE PENELITIAN}

Penelitian ini termasuk penelitian eksperimen dengan melibatkan dua kelompok siswa dengan perlakuan yang 
berbeda dalam pembelajaran yaitu kelompok eksperimen 1 dan kelompok eksperimen 2. Untuk kelompok eksperimen 1 diajar dengan menggunakan pembelajaran matematika dengan pendekatan problem solving sedangkan pada kelas eksperimen 2 diajar dengan menggunakan pendekatan problem posing.

Variabel yang akan diselidiki dalam pada penelitian ini terdiri dari dua jenis, yaitu variabel terikat dan variabel bebas. Hasil belajar matematika siswa sebagai variabel terikat dan pendekatan pembelajaran sebagai variabel bebas. Pendekatan pembelajaran yang akan diterapkan terdiri dari dua pendekatan, yaitu pendekatan problem solving (diberikan pada kelompok eksperimen 1) dan pendekatan problem posing (diberikan pada kelompok eksperimen 2).

Desain penelitian yang digunakan adalah sebagai berikut:

\begin{tabular}{|c|c|c|c|c|}
\hline & Grup & Pretest & Variabel Terikat & Posttest \\
\hline$(\mathrm{R})$ & Eksperimen 1 & Y1 & T1 & Y2 \\
$(\mathrm{R})$ & Eksperimen 2 & Y1 & T2 & Y2 \\
\hline
\end{tabular}

Keterangan:

$\begin{array}{ll}\mathrm{E} & : \text { Kelas Eksperimen } \\ \mathrm{K} & : \text { Kelas Kontrol } \\ \mathrm{R} & : \text { Random } \\ \mathrm{T} & : \text { Treatment (perlakuan) } \\ \mathrm{Y}_{1} & : \text { Pretest sebelum perlakuan } \\ \mathrm{Y}_{2} & : \text { Postes setelah perlakuan }\end{array}$

Adapun desain penelitian yang digunakan dalam peneliatian ini adalah rancangan dengan jenis Desain Kelompok Kontrol Pretest - Postest (The Pretest - Posttest Control Group Design). Rancangan penelitian ini melibatkan dua kelompok belajar yang diambil secara acak. Dimana satu kelas dijadikan kelas eksperimen 1 dan satu kelas eksperimen 2, kemudian diberi pretest untuk mengetahui keadaan awal adakah perbedaan antara kelompok eksperimen 1 dan kelompok eksperimen 2.

Pendekatan mengajar yang dimaksudkan dalam penelitian ini adalah cara yang digunakan guru untuk mengajarkan bidang studi matematika. Pendekatan mengajar yang akan diterapkan dalam penelitian ini terdiri atas dua pendekatan yaitu, problem solving dan problem posing.

Hasil belajar matematika yang dimaksudkan dalam penelitian ini adalah nilai yang diperoleh siswa setelah perlakuan dilaksanakan.

a. Populasi Penelitian

Adapun populasi dari penelitian ini adalah seluruh siswa kelas IV SD Swasta Rama Sejahtera Kota Makassar pada tahun ajaran 2018/2019 yang terdiri dari tiga kelas.

b. Sampel Penelitian

Sampel dari penelitian ini terdiri dari dua kelas yang berjumlah 50 orang. Jenis pengambilan sampel yang digunakan adalah random sampling. Melalui teknik ini diperoleh kelas IVA sebagai kelas eksperimen 1 dan kelas IVB sebagai kelas eksperimen 2 . Masing-masing kelas terdiri dari 25 orang siswa.

Setelah menetapkan subjek penelitian, maka pelaksanaan penelitian dilaksanakan sebagai berikut: 
a. Menetapkan masing-masing siswa yang dijadikan subjek penelitian ke dalam dua kelompok, yaitu kelompok eksperimen 1 dan kelompok eksperimen 2.

b. Memberikan tes awal kepada kedua kelompok, dengan soal yang sama.

c. Melakukan kegiatan pembelajaran pada kelompok eksperimen 1 dan kelompok eksperimen 2 sesuai perlakuan dengan frekuensi pertemuan yang sama (4 kali pertemuan).

d. Setelah pembelajaran pada kedua kelompok, setiap responden diberikan tes hasil belajar dengan soal yang sama untuk kedua kelompok tersebut.

e. Melakukan analisis pada data pretest dan posttest yang telah dikumpulkan.

Instrumen yang digunakan dalam penelitian ini adalah tes hasil belajar matematika yang terdiri atas pretest dan postest. Pretest digunakan untuk mengetahui kemampuan awal siswa, sedangkan posttest digunakan untuk mengetahui kemampuan siswa setelah diberi perlakuan.

Penyusunan tes hasil belajar matematika yang didasarkan pada kisikisi tes yang meliputi materi semester genap tahun pelajaran 2018/2019. Itemitem tes dibuat pada materi yang diberikan selama penelitian yang terdapat pada semester ganjil kelas IV.

Pengumpulan data untuk hasil belajar siswa dilakukan dengan pemberian tes hasil belajar pada akhir perlakuan secara serentak kepada masing-masing responden pada kedua kelompok, yatu kelompok eksperimen 1 dan kelompok eksperimen 2. Data yang diperoleh merupakan data empirik yang kemudian akan dianalisis.

Metode observasi menggunakan lembar pengamatan keterampilan proses peserta didik untuk mengamati kegiatan peserta didik dan lembar pengamatan untuk mengamati kemampuan guru dalam mengelola pembelajaran yang diharapkan muncul dalam pembelajaran matematika dengan pendekatan problem solving dan problem posing

Teknik analisis data yang digunakan untuk menganalisis data yang diperoleh adalah dengan menggunakan analisis statistika deskriptif dan analisis statistika inferensial.

a. Analisis Statistik Deskriptif

Statistik deskriptif adalah statistik yang digunakan untuk menganalisis data dengan cara mendeskripsikan atau menggambarkan data yang telah terkumpul sebagaimana adanya, tanpa bermaksud membuat kesimpulan yang berlaku umum atau generalisasi, (Sugiyono, 2013). Dalam penelitian ini, analisis statistik deskriptif digunakan untuk mendeskripsikan hasil belajar matematika siswa pada setiap kelompok yang telah dipilih.

Termasuk dalam statistik deskriptif antara lain penyajian data melalui tabel, grafik, diagram lingkaran, pictogram, perhitungan modus, median, mean, perhitungan desil, persentil, standar deviasi, perhitungan penyebaran data melalui perhitungan rata-rata dan standar deviasi, perhitungan persentase, (Sugiyono, 2013).

Jenis data berupa hasil belajar selanjutnya dikategorikan secara kualitatif berdasarkan teknik standar pengkategorian dengan skala lima, yaitu: 
Tabel 1. Interpretasi Kategori Nilai Hasil Belajar

\begin{tabular}{|c|c|}
\hline Skor & Kategori \\
\hline $00-54$ & Sangat rendah \\
\hline $55-64$ & Rendah \\
\hline $65-79$ & Sedang \\
\hline $80-89$ & Tinggi \\
\hline $90-100$ & Sangat tinggi \\
\hline
\end{tabular}

Disamping itu hasil belajar siswa juga diarahkan pada pencapaian hasil belajar secara individual.Kriteria seorang siswa dikatakan tuntas belajar apabila memenuhi kriteria ketuntasan minimal yang ditentukan oleh sekolah yakni 60 .

b. Analisis Statistik Inferensial

Statistik inferensial adalah teknik statistik yang digunakan untuk menganalisis data sampel dan hasilnya diberlakukan untuk populasi. Teknik statistik ini dimaksudkan untuk menguji hipotesis penelitian.Sebelum menguji hipotesis penelitian, dilakukan uji normalitas dan uji homogenitas.

a) Uji Normalitas

Uji normalitas merupakan langkah awal dalam menganalisis data secara spesifik.Uji normalitas digunakan untuk mengetahui data berdistribusi normal atau tidak. Pada penelitian ini digunakan uji One Sample KolmogorovSmirnov dengan menggunakan taraf signifikansi $5 \%$ atau 0,05 , dengan syarat:

Jika $\mathrm{P}_{\text {value }} \geq 0,05$ maka distribusinya adalah normal

Jika $\mathrm{P}_{\text {value }}<0,05$ maka distribusinya adalah tidak normal.

b) Uji Homogenitas

Uji homogenitas dilakukan untuk menyelidiki variansi kedua sampel sama atau tidak. Uji yang digunakan adalah uji Levene's Test. Uji ini dilakukan sebagai prasyarat dalam analisis uji independent sampel t-test. Jika sampel tersebut memiliki variansi yang sama, maka keduanya dikatakan homogen. Pada uji Levene's Test digunakan taraf signifikansi $5 \%$ atau 0,05 . Kriteria pengujian hipotesis adalah jika signifikansi lebih besar dari taraf signifikansi $\alpha=0,05$, maka secara statistik kedua varian sama atau data homogen.

\section{HASIL DAN PEMBAHASAN}

A. Data Hasil Penelitian

1) Hasil Analisis statistik deskriptif

a. Deskripsi Hasil Belajar Siswa Kelas IVA yang di Ajar Melalui Pendekatan Problem Solving

Berikut ini adalah hasil analisis statistik deskriptif terhadap hasil tes belajar pada kelas yang diajar dengan pendekatan problem solving setelah dilakukan pretest dan posttest dapat dilihat pada tabel 2 di bawah ini.

Tabel 2. Hasil Analisis Statistik Deskriptif pretest dan posttest

\begin{tabular}{|c|c|c|}
\hline \multirow{2}{*}{ Statistik } & \multicolumn{2}{|c|}{ Nilai Statistik } \\
\cline { 2 - 3 } & Pretest & Posttest \\
\hline Jumlah Sampel & 25 & 25 \\
\hline Nilai Terendah & 25,00 & 55,00 \\
\hline Nilai Tertinggi & 79,00 & 95,00 \\
\hline Nilai rata-rata $(\bar{x})$ & 53,40 & 73,36 \\
\hline Standar deviasi & 14,04 & 10,20 \\
\hline
\end{tabular}

Berdasarkan perbandingan hasil pretest dan posttest dapat dilihat bahwa terjadi peningkatan hasil belajar siswa meski peningkatannya tidak terlalu signifikan. Nilai terendah pada pretest, yaitu 25,00 setelah dilakukan posttest meningkat menjadi 55,00. Nilai tertinggi pada pretest yaitu 79,00 setelah dilakukan posttest meningkat menjadi 95,00. Nilai rata-rata hasil belajar pada pretest yaitu 53,40 setelah dilakukan posttest meningkat menjadi 73,36 . Hal ini menunjukkan bahwa setelah diterapkan pendekatan problem solving hasil belajar siswa kelas IV SD Swasta Rama Sejahtera Kota Makassar 
pada Mata pelajaran Matematika mengalami peningkatan.

Jika hasil belajar siswa dikelompokkan dalam kategori sangat rendah, rendah, sedang, tinggi, dan sangat tinggi akan diperoleh frekuensi dan presentase untuk kelompok yang diberi perlakuan melalui pendekatan problem solving setelah dilakukan pretest dan posttest. Tabel distribusi frekuensi dan presentase hasil belajar siswa pada mata pelajaran matematika kelas IV SD Swasta Rama Sejahtera Kota Makassar adalah sebagai berikut:

Tabel 3. Distribusi Frekuensi dan Persentase Hasil Belajar Siswa Kelas IV.A SD Swasta Rama Sejahtera Kota Makassar

\begin{tabular}{|c|c|c|c|c|c|}
\hline Tingkat & \multirow{2}{*}{ Kategori } & \multicolumn{2}{|c|}{ Pretest } & \multicolumn{2}{|c|}{ Posttest } \\
\cline { 3 - 6 } Penguasaan & & Frek & $\%$ & Frek & $\%$ \\
\hline $00-54$ & $\begin{array}{c}\text { Sangat } \\
\text { rendah }\end{array}$ & 10 & 40 & 0 & 0 \\
\hline $55-64$ & Rendah & 9 & 36 & 3 & 12 \\
\hline $65-79$ & Sedang & 6 & 24 & 18 & 72 \\
\hline $80-89$ & Tinggi & 0 & 0 & 1 & 4 \\
\hline $90-100$ & $\begin{array}{c}\text { Sangat } \\
\text { tinggi }\end{array}$ & 0 & 0 & 3 & 12 \\
\hline
\end{tabular}

Berdasarkan pada tabel 3 di atas, maka dapat diketahui bahwa hasil belajar siswa pada mata pelajaran matematika setelah dilakukan pretest dan posttest melalui pendekatan Problem Solving, yaitu:

a) Hasil pretest kelas IVA yaitu: terdapat $76,00 \%$ pada kategori sangat rendah dan rendah, dan $24,00 \%$ berada pada kategori sedang.

b) Hasil posttest Kelas IVA yaitu: terdapat $12,00 \%$ berada pada kategori rendah, dan $88,00 \%$ berada pada kategori sedang, kategori tinggi, dan kategori sangat tinggi.

\section{b. Deskripsi Hasil Belajar Siswa Kelas IV.B SD Swasta Rama Sejahtera Kota Makassar melalui Pendekatan Problem Posing}

Berikut ini adalah hasil analisis statistik deskriptif terhadap hasil tes belajar pada kelas VII yang telah diajar dengan pendekatan problem posing setelah dilakukan pretest dan posttest yang dapat dilihat pada tabel 4 sebagai berikut.

Tabel 4. Nilai Statistik deskriptif hasil pretest dan posttest Kelas IV.B

\begin{tabular}{|l|c|c|}
\hline \multirow{2}{*}{ Statistik } & \multicolumn{2}{|c|}{ Nilai Statistik Kelas IV.B } \\
\cline { 2 - 3 } & Pre test & Post test \\
\hline Jumlah Sampel & 25 & 25 \\
\hline Nilai Terendah & 30,00 & 55,00 \\
\hline Nilai Tertinggi & 70,00 & 85,00 \\
\hline Nilai rata-rata $(\bar{x})$ & 53,48 & 67,96 \\
\hline Standar deviasi & 12,96 & 8.29 \\
\hline
\end{tabular}

Berdasarkan perbandingan hasil pretest dan posttest dapat dilihat bahwa terjadi peningkatan hasil belajar siswa meski peningkatannya tidak terlalu signifikan. Nilai terendah pada pretest, yaitu 30,00 setelah dilakukan posttest meningkat menjadi 55,00. Nilai tertinggi pada pretest yaitu 70,00 setelah dilakukan posttest meningkat menjadi 85,00. Nilai rata-rata hasil belajar pada pretest yaitu 53,48 setelah dilakukan posttest meningkat menjadi 67,96. Hal ini menunjukkan bahwa setelah diterapkan pendekatan problem posing hasil belajar siswa kelas IV SD Swasta Rama Sejahtera Kota Makassar pada mata pelajaran matematika mengalami peningkatan.

Jika hasil belajar siswa dikelompokkan dalam kategori sangat rendah, rendah, sedang, tinggi, dan sangat tinggi akan diperoleh frekuensi dan presentase untuk kelompok yang diberi perlakuan pendekatan problem posing setelah dilakukan pretest dan posttest. Tabel distribusi frekuensi dan presentase hasil belajar siswa pada mata pelajaran matematika kelas IV SD Swasta Rama Sejahtera Kota Makassar. 
Tabel 5. Distribusi Frekuensi dan

Presentase Hasil Belajar Siswa Kelas IV.B

SD Swasta Rama Sejahtera Kota Makassar

Melalui PendekatanProblem Posing

\begin{tabular}{|c|c|c|c|c|c|}
\hline Tingkat & \multirow{2}{*}{ Kategori } & \multicolumn{2}{|c|}{ Pretest } & \multicolumn{2}{c|}{ Posttest } \\
\cline { 3 - 6 } Penguasaan & & Frek & $\%$ & Frek & $\%$ \\
\hline $00-54$ & Sangat rendah & 12 & 48 & 0 & 0 \\
\hline $55-64$ & Rendah & 6 & 24 & 8 & 32 \\
\hline $65-79$ & Sedang & 7 & 28 & 14 & 56 \\
\hline $80-89$ & Tinggi & 0 & 0 & 3 & 12 \\
\hline $90-100$ & Sangat tinggi & 0 & 0 & 0 & 0 \\
\hline
\end{tabular}

Berdasarkan pada tabel 5, maka dapat diketahui bahwa hasil belajar siswa pada mata pelajaran matematika setelah dilakukan pretest dan posttest dengan pendekatan problem posing, yaitu:

a. Hasil pretest kelas VII yaitu: terdapat $28,00,00 \%$ berada pada kategori sedang dan $72,00 \%$ berada pada kategori rendah dan kategori sangat rendah.

b. Hasil posttest Kelas VII yaitu : terdapat $88,00 \%$ pada kategori tinggi dan kategori sedang dan $12,00 \%$ pada kategori.

\section{2) Hasil Analisis Statistika Inferensial Setelah Penerapan Pendekatan Problem Solving dan Problem Posing}

Hasil statistika inferensial dimaksudkan untuk menjawab hipotesis penelitian yang telah dirumuskan, dan sebelum melakukan analisis statistika inferensial terlebih dahulu dilakukan beberapa pengujian persyaratan analisis, antara lain:

a. Uji normalitas

Untuk uji normalitas digunakan Kolmogorov-Smirnov dengan bantuan SPSS 20. Hasil perhitungan yang diperoleh untuk nilai kelas eksperimen 1 diperoleh nilai $p$-value $>\alpha$ yaitu $0,079>\alpha$ (taraf signifikansi $\alpha=0,05$ ), sedangkan hasil perhitungan yang diperoleh untuk nilai kelas eksperimen 2 diperoleh nilai $p$-value $>\alpha$ yaitu 0,86 $>\alpha$ (taraf signifikansi $\alpha=0,05$ ). Kriteria pengujiannya adalah data berdistribusi normal jika $p$-value $>\alpha$. Sehingga dapat disimpulkan bahwa nilai kelas eksperimen 1 dan nilai kelas eksperimen 2 termasuk kategori normal.

b. Uji Homogenitas

Uji homogenitas digunakan untuk mengetahui beberapa varian data adalah sama atau tidak. Uji yang digunakan adalah uji kesamaan varian (homogenitas) dengan Levene's Test. Dengan program Statistical Package for Social Sciense (SPSS 20) diperoleh hasil perhitungan dengan nilai $p$-value $>\alpha$ yaitu 0,46 > 0,05. Kriteria pengujiannyaadalah kedua varian sama jika nilai $p$-value $>\alpha$. Jadi dapat disimpulkan bahwa nilainya memiliki varian yang sama.

c. Uji hipotesis

Hipotesis dalam penelitian ini diuji dengan menggunakan uji-T menggunakan Equal Variance Assumed (varian sama). Langkah-langkah uji hipotesis adalah sebagai berikut:

1) Menentukan t hitung. Dari tabel hasil SPSS diperoleh nilai t hitung sebesar 2,053 .

2) Menentukan t tabel. Dengan menggunakan tingkat keyakinan (1 $\alpha)=95 \%, \alpha=5 \%$, dan $\mathrm{dk}=$ $n_{1}+n_{2}-2$ atau $25+25-2=48$, hasil diperoleh untuk t tabel sebesar 1,67 .

3) Kriteria pengujian

$\mathrm{H}_{0}$ diterima jika $\mathrm{t}$ hitung $\leq \mathrm{t}$ tabel $\mathrm{H}_{0}$ ditolak jika $\mathrm{t}$ hitung $>\mathrm{t}$ tabel

4) Membandingkan $t$ hitung dengan $t$ tabel. Nilai $\mathrm{t}$ hitung $>\mathrm{t}$ tabel $(2,053>$ 1,67), maka $\mathrm{H}_{0}$ ditolak 
5) Menarik kesimpulan. Karena t hitung $>\mathrm{t}$ tabel $(2,053>1,67)$, maka $\mathrm{H}_{0}$ ditolak. Hal ini berarti bahwa hasil belajar matematika siswa yang diajar dengan menggunakan pendekatan problem solving berbeda dengan hasil belajar siswa yang diajar dengan menggunakan pendekatan problem posing.

\section{3) Uji Hasil Analisis Observasi Aktivitas Siswa}

Di samping adanya peningkatan hasil belajar terdapat pula perubahan sikap siswa baik berupa perhatian, motivasi, maupun semangat siswa dalam mengikuti proses belajar mengajar di kelas. Perubahan tersebut merupakan data kualitatif yang diperoleh dari lembar observasi pada setiap pertemuan yang dicatat oleh observer. Perubahan ini dapat dilihat dari hal-hal berikut ini dapat dilihat pada gambar 1 dan gambar 2 .

- Problem solving $3 x$ tatap muka $\quad$ P.Solving \%

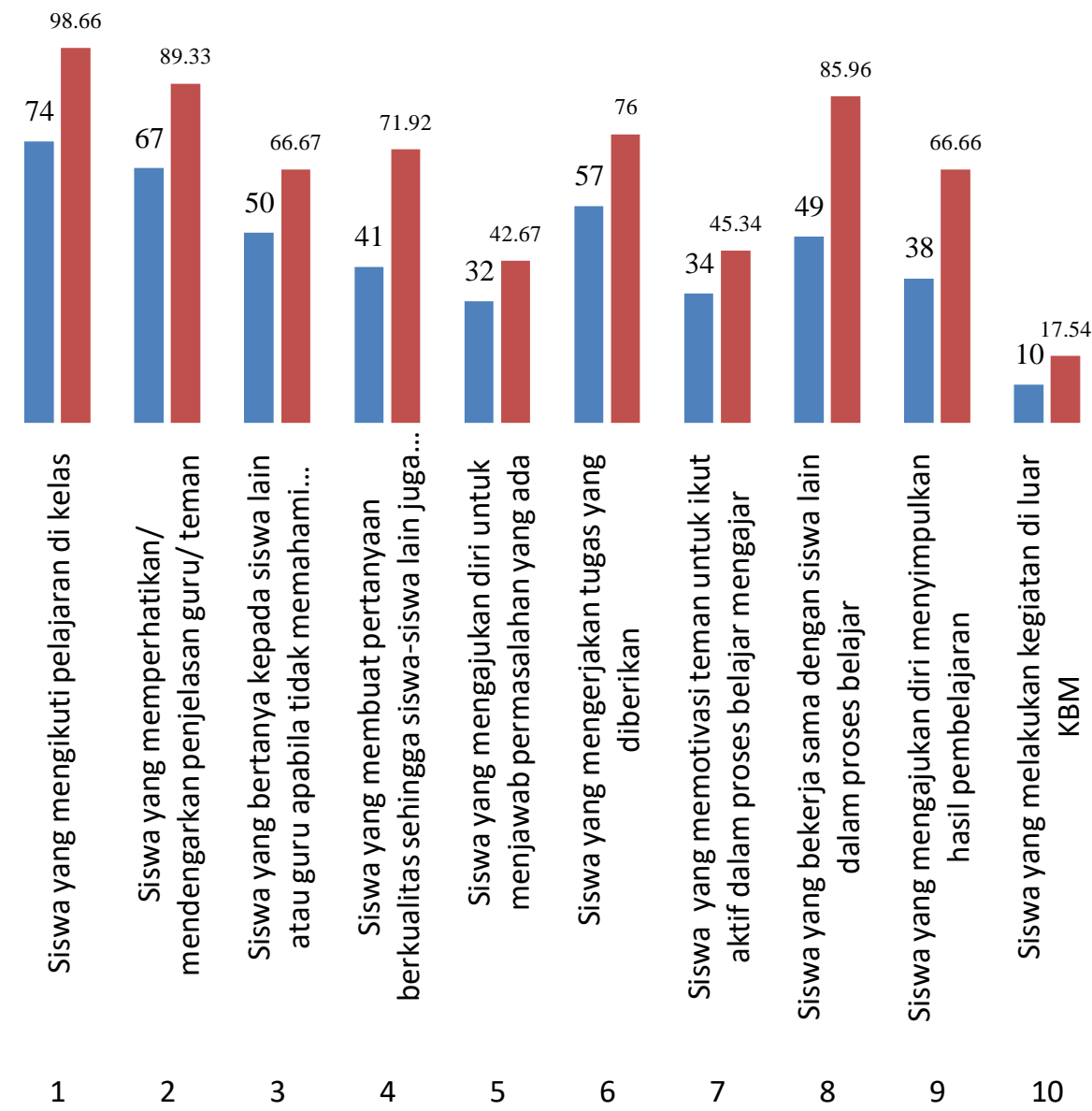

Gambar 1.Grafik hasil analisis observasi aktivitas siswa pada kelas menggunakan pendekatan problem solving 


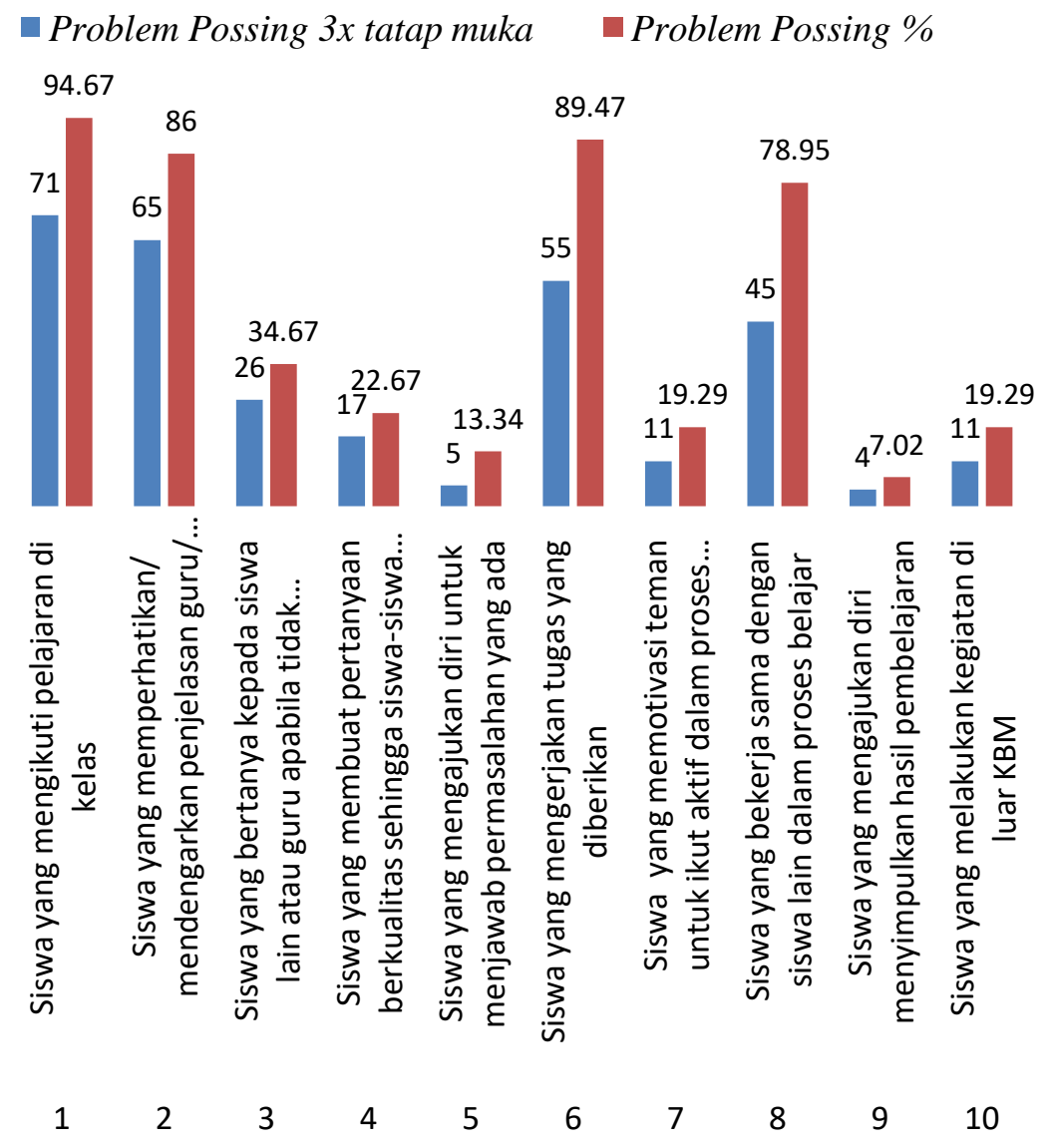

Gambar 2.Grafik hasil analisis observasi aktivitas siswa pada kelas menggunakan pendekatan problem possing

Berdasarkan gambar 1 dan gambar 2 di atas, maka dapat di deskripsikan hasil observasi aktivitas siswa sebagai berikut:

a. Mengikuti pelajaran di kelas. Pada kelas eksperimen 1, persentase siswa yang mengikuti pelajaran sebesar 98,66\%, sedangkan pada kelas eksperimen 2 terdapat $94,67 \%$ siswa yang mengikuti pelajaran.

b. Memperhatikan/mendengarkan penjelasan guru/teman. Perhatian siswa pada kelas eksperimen 1 dalam menyimak dan mendengarkan penjelasan guru/ teman pada saat proses belajar mengajar sangat baik, hal ini terbukti dari $89,33 \%$ siswa yang aktif dalam kelas pada saat proses belajar mengajar berlangsung. Sedangkan pada kelas eksperimen 2 , terdapat $86,00 \%$ siswa yang aktif menyimak dan mendengarkan penjelasan teman/guru.

c. Bertanya kepada siswa lain atau guru apabila tidak memahami persoalan yang dihadapinya. Pada kelas eksperimen 1, siswa merasa tidak terlalu canggung dan cemas lagi untuk menanyakan hal-hal yang belum dipahami, hal ini tampak dari $66,67 \%$ siswa aktif bertanya. Sedangkan pada kelas eksperimen 2, dominasi siswa tidak terlalu nampak, mereka terlihat ragu dan enggan bertanya 
meskipun belum paham, hal ini dilihat dari $34,67 \%$ siswa yang aktif bertanya.

d. Membuat pertanyaan berkualitas sehingga siswa-siswa lain juga tertarik dalam memecahkan masalah.Pada kelas eksperimen 1, tampak bahwa ada 71,92 \% siswa yang mampu membuat pertanyaan berkualitas. Sedangkan, pada kelas eksperimen 2, hanya $22,67 \%$ siswa yang aktif membuat pertanyaan berkualitas.

e. Mengajukan diri untuk menjawab permasalahan yang ada. Pada kelas eksperimen 1 terdapat $42,67 \%$ siswa yang aktif untuk mengajukan diri untuk menjawab permasalahan yang ada, sedangkan pada kelas eksperimen 2, terdapat $13,34 \%$ siswa.

f. Mengerjakan tugas yang diberikan. Untuk melatih pemahaman siswa akan materi yang diajarkan, sering kali guru memberi tugas kepada para siswa. Pada kelas eksperimen 1 terdapat $76,00 \%$ yang aktif mengerjakan tugas, dan terdapat $89,47 \%$ siswa aktif mengerjakan tugas pada kelas eksperimen 2.

g. Memotivasi teman untuk ikut aktif dalam proses belajar mengajar. Kesadaran menjadi pemimpin dalam kelompok, salah satunya dapat dilihat dari kemampuan memotivasi teman yang lain untuk aktif dalam belajar. Pada kelas eksperimen 1 terdapat $45,34 \%$ siswa yang aktif, sedangkan pada kelas eksperimen 2, terdapat $19,29 \%$ siswa aktif.

h. Bekerja sama dengan siswa lain dalam proses belajar. Pada kelas eksperimen 1 terdapat $85,96 \%$ siswa yang aktif dalam bekerja sama dalam proses belajar, sedangkan pada kelas eksperimen 2 , terdapat $78,95 \%$ siswa.

i. Mengajukan diri menyimpulkan hasil pembelajaran. Menarik sebuah kesimpulan bukanlah hal mudah, namun pada kelas eksperimen 1, persentase siswa mengajukan diri sebesar $66,66 \%$. Pada kelas eksperimen 2 terdapat $7,02 \%$ siswa.

j. Melakukan kegiatan di luar KBM. Timbulnya kesadaran pada diri siswa yang ditandai dengan kurangnya siswa yang melakukan kegiatan di luar KBM seperti mengantuk, tidur, melamun, dsb. Pada kelas eksperimen 1 terdapat $17,54 \%$ siswa melakukan kegiatan di luar KBM. Pada kelas eksperimen 2 terdapat 19,29\% siswa melakukan kegiatan di luar KBM.

Dari kesepuluh aktivitas di atas, persentase rata-rata untuk kelas eksperimen 1 sebesar $66,75 \%$ siswa aktif dalam kelas selama proses belajar mengajar dengan penggunaan pendekatan problem solving lebih besar dari kelas eksperimen 2 yaitu kelas yang diajar dengan pendekatan problem posing, persentase rata-ratanya sebesar $46,53 \%$ siswa aktif. Hal ini menunjukkan bahwa penerapan pendekatan problem solving lebih baik digunakan dalam kegiatan belajar mengajar khususnya untuk mata pelajaran matematika di kelas IV SD Swasta Rama Sejahtera Kota Makassar.

\section{4) Hasil Analisis Observasi Kemampuan Guru Dalam Mengelola Pembelajaran}


Hasil penelitian ini menunjukkan bahwa, aspek dari pengelolaan pembelajaran yang dilaksanakan oleh guru di kelas pada saat mengajar memperoleh kriteria yang sangat baik. Penilaian tersebut dapat ditunjukkan dari perolehan nilai di atas $75 \%$ untuk setiap aspek pengelolaan pembelajaran yang meliputi: 1) penyusunan rencana pembelajaran, 2) keterampilan guru dalam mengajar, 3) penilaian hasil belajar, dan 4) pelaksanaan tindak lanjut. Perolehan nilai tersebut diperoleh dari rata-rata setiap aspek pengelolaan pembelajaran yang rinciannya sebagai berikut: 1) penyusunan rencana pembelajaran memperoleh $84 \%, 2$ ) keterampilan guru dalam mengajar memperoleh $72 \%, 3$ ) penilaian hasil belajar memperoleh $71 \%$, dan 4) pelaksanaan tindak lanjut memperoleh $73 \%$. Hal tersebut menunjukkan bahwa guru mampu dalam pengelolaan pembelajaran di kelas, meskipun terdapat hal-hal yang masih kurang diperhatikan.

\section{B. Pembahasan}

Hasil analisis statistika deskriptif menunjukkan bahwa hasil belajar matematika kelas IV SD Swasta Rama Sejahtera Kota Makassar pada mata pelajaran matematika yang diajar dengan menggunakan pendekatan problem solving dikategorikan tinggi. Hal ini terlihat dari skor rata-rata sebesar73,36 dari skor ideal 100 dengan standar deviasi 10,20. Berdasarkan kriteria ketuntasan, Tidak ada siswa yang berada pada kategori sangat rendah, 3 orang siswa $(12,00 \%)$ berada pada kategori rendah, 18 orang siswa $(72,00 \%)$ berada pada kategori sedang, 1 orang siswa $(4,00 \%)$ berada pada kategori tinggi, dan 3 orang siswa $(12,00 \%)$ berada pada kategori sangat tinggi.
Sementara itu hasil belajar matematika siswa yang diajar dengan pendekatan problem posing dikategorikan rendah. Hal ini terlihat dari skor rata-rata sebesar 67,96 dari skor ideal 100 dengan standar deviasi 8,29 . Berdasarkan kriteria ketuntasan, diketahui bahwa pada kategori tinggi dan terdapat 3 orang siswa $(32,00 \%)$, 14 orang siswa pada kategori sedang (56,00\%), sedangkan pada kategori rendah terdapat 8 orang siswa $(12,00 \%)$ dan tidak ada siswa yang berada pada kategori sangat rendah. Berdasarkan kriteria ketuntasan minimal (KKM) pada SD Swasta Rama Sejahtera Kota Makassar, yaitu siswa dikatakan tuntas belajarnya jika hasil belajarnya telah mencapai skor 60 .

Hasil analisis inferensial menunjukkan bahwa terdapat perbedaan hasil belajar matematika siswa yang diajar dengan menggunakan pendekatan problem solving dengan siswa yang diajar dengan pendekatan problem posing, di mana hasil belajar siswa yang diajar dengan menggunakan pendekatan problem solving lebih tinggi dibandingkan dengan hasil belajar siswa yang diajar dengan pendekatan problem posing. Hal ini ditunjukkan oleh nilai $\mathrm{t}_{\text {hitung }}>\mathrm{t}_{\text {tabel }}$ yaitu $2,053>1,67$. Selain itu, dari aspek aktivitas siswa pendekatan problem solving lebih efektif dalam meningkatkan aktivitas siswa dibandingkan pendekatan problem posing. Hal ini ditandai melalui rata-rata presentase untuk kelas eksperimen siswa aktif dalam kelas selama proses belajar mengajar dengan penggunaan pendekatan problem solving lebih besar yaitu sebesar $66,75 \%$, sedangkan rata-rata presentase untuk kelas kontrol siswa kurang aktif 
dalam kelas selama proses belajar mengajar dengan penggunaan pendekatan problem posing lebih besar yaitu sebesar 46,53\%. Berdasarkan hal tersebut, maka dapat disimpulkan bahwa penerapan pendekatan problem solving lebih baik digunakan dalam kegiatan belajar mengajar khususnya untuk mata pelajaran matematika di kelas IV SD Swasta Rama Sejahtera Kota Makassar.

Hasil penelitian di atas relevan dengan hasil penelitian Widha \& Agus (2015) yang hasil penelitiannya menunjukkan bahwa pendekatan pembelajaran (problem solving dengan setting kooperatif dan problem posing dengan setting kooperatif) efektif dan pendekatan problem posing dengan setting kooperatif lebih efektif daripada pendekatan problem solving dengan setting kooperatif pada pembelajaran matematika ditinjau dari ketercapaian standar kompetensi, kemampuan berpikir kritis, dan kecerdasan emosional siswa. Lebih lanjut penelitian Palobo (2016) hasil penelitiannya menunjukkan bahwa (1) pendekatan problem posing efektif ditinjau dari sikap terhadap Kalkulus dan prestasi belajar; (2) pendekatan problem solving efektif ditinjau dari prestasi belajar; dan (3) pendekatan problem posing lebih efektif dari pada pendekatan problem solving ditinjau dari sikap mahasiswa terhadap Kalkulus.

\section{KESIMPULAN}

Berdasarkan hasil dan pembahasan penelitian dapat disimpulkan, bahwa (1) Hasil belajar matematika siswa kelas IV.A SD Swasta Rama Sejahtera Kota Makassar yang diajar melalui pendekatan problem solving memiliki skor rata-rata sebesar 73,36 dengan standar deviasi 10,20 dari skor ideal 100; (2) Hasil belajar matematika siswa kelas IV.B SD Swasta Rama Sejahtera Kota Makassar yang diajar melalui pendekatan problem posing memiliki skor rata-rata sebesar 67,96 dengan standar deviasi 8,29 dari skor ideal 100; (3) Terdapat perbedaan hasil belajar yang signifikan antara siswa yang diajar dengan pendekatan problem solving dan pendekatan problem posing. Pendekatan problem solving lebih baik digunakan dalam kegiatan belajar mengajar khususnya untuk mata pelajaran matematika di kelas IV SD Swasta Rama Sejahtera Kota Makassar.

\section{DAFTAR PUSTAKA}

Palobo, M. (2016). Keefektifan pendekatan Problem posing dan problem solving dalam pembelajaran kalkulus II. Jurnal Riset Pendidikan Matematika, 3(2), 234-244.

Sugiyono. (2013). Metode Pelitian Kuantitatif Kualitatif dan $R \& D$. Bandung: Alfabeta.

Siswono, T. Y. E. (2008). Identifikasi Proses Berpikir Kreatif Siswa dalam Pengajuan Masalah (Problem Posing) Matematika Berpandu dengan Model Wallas dan Creative Problem Solving (CPS). Buletin Pendidikan Matematika, 6(2), 1-16.

Widha N. S, \& Agus M.A. (2015). Keefektifan Pendekatan Problem Solving dan Problem Posing dengan Setting Kooperatif dalam Pembelajaran Matematika. Jurnal Riset Pendidikan Matematika, 2(1), 121-134 Available online at JRPM Website: http://journal.uny.ac.id/index.php/jr pm/index 
